\title{
Two pulse intrusive events of the Pliocene Tanigawa-dake granites revealed from zircon $\mathrm{U}-\mathrm{Pb}$ dating
}

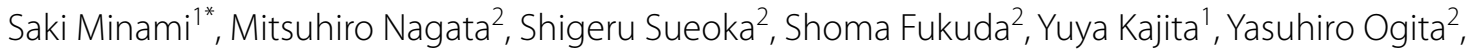
Saya Kagami ${ }^{2}$, Tatsunori Yokoyama ${ }^{2}$ and Takahiro Tagami ${ }^{1}$

\begin{abstract}
We performed zircon U-Pb dating on the Pliocene Tanigawa-dake granites (Makihata and Tanigawa bodies) and the Cretaceous Minakami quartzdiorite, Northeast Japan Arc. Concordia ages were estimated to be $3.95 \pm 0.11 \mathrm{Ma}( \pm 2$ sigma) for the Makihata body, 3.18 $\pm 0.13 \mathrm{Ma}$ and 3.32 $\pm 0.15 \mathrm{Ma}$ for the Tanigawa body, and $109.4 \pm 2.2 \mathrm{Ma}$ for the Minakami quartzdiorite. The Minakami quartzdiorite is possibly correlated to the bedrock in the Ashio belt because the age of the Minakami quartzdiorite is consistent with the zircon U-Pb ages of the earliest Tadamigawa granites (107-62 Ma) which are distributed to the northeast of the Tanigawa-dake region and belong to the Ashio belt. All the zircon U-Pb ages of the Tanigawa-dake granites are older than the previously reported cooling ages, i.e., K-Ar ages and zircon fission-track ages, being consistent with their difference in closure temperature. On the basis of these results, we concluded that the intrusive ages of the Tanigawa-dake granites are $4-3 \mathrm{Ma}$, which are among the youngest exposed plutons on Earth. The U-Pb ages of the Makihata body and the Tanigawa body are different significantly in the 2 sigma error range. Thus, the Tanigawa body intruded later than the Makihata body by $0.7 \mathrm{Myr}$.
\end{abstract}

Keywords: Pliocene granites, Tanigawa-dake granites, Minakami quartzdiorite, Zircon U-Pb dating

${ }^{*}$ Correspondence: minami.saki.34m@st.kyoto-u.ac.jp

${ }^{1}$ Department of Geology and Mineralogy, Graduate School of Science, Kyoto

University, Oiwake-cho, Kitashirakawa, Sakyo-ku, Kyoto 606-8502, Japan

Full list of author information is available at the end of the article give appropriate credit to the original author(s) and the source, provide a link to the Creative Commons licence, and indicate if changes were made. The images or other third party material in this article are included in the article's Creative Commons licence, unless indicated otherwise in a credit line to the material. If material is not included in the article's Creative Commons licence and your intended use is not permitted by statutory regulation or exceeds the permitted use, you will need to obtain permission directly from the copyright holder. To view a copy of this licence, visit http://creativecommons.org/licenses/by/4.0/. 


\section{Graphical Abstract}
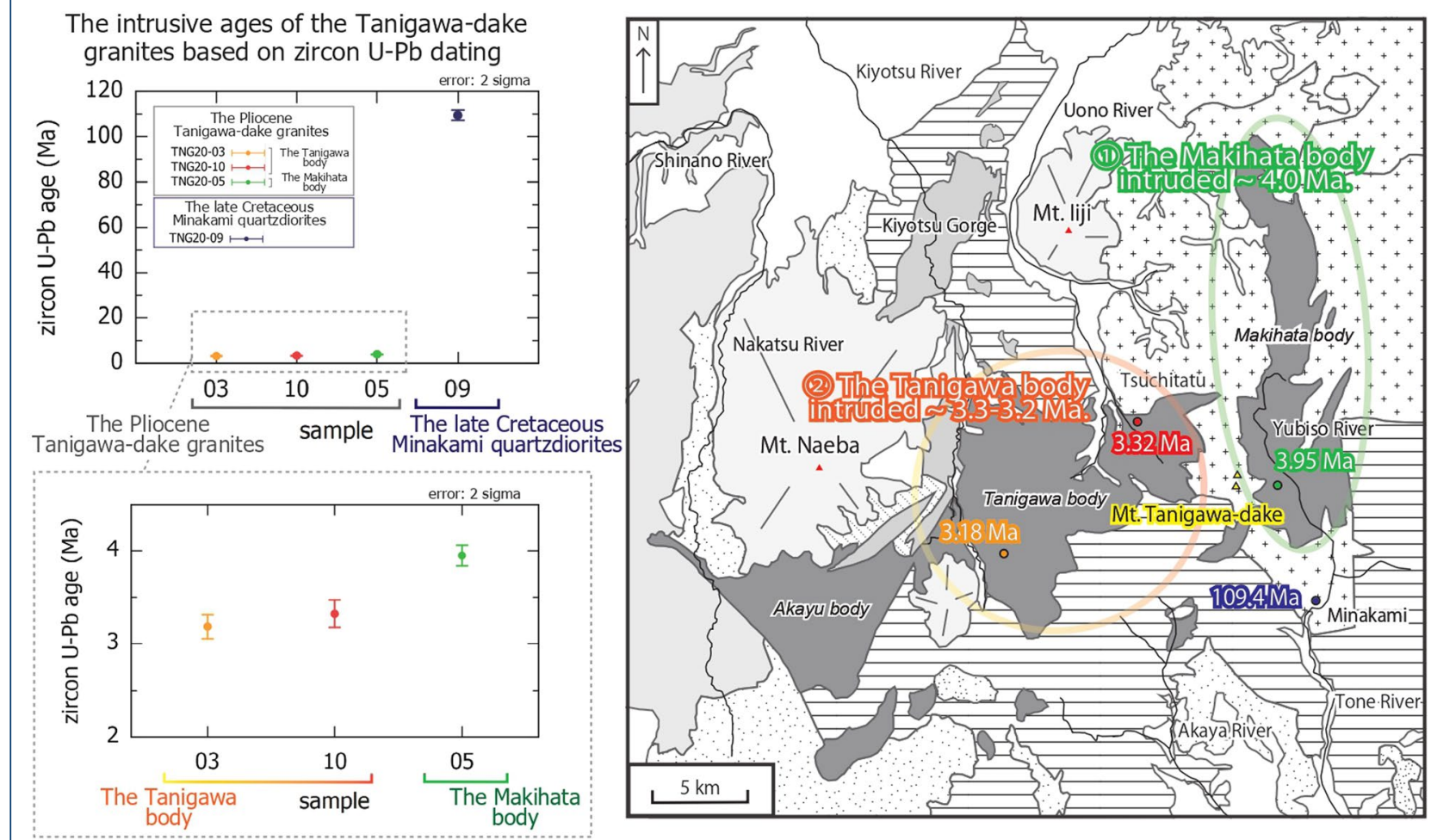

\section{Introduction}

Granites are formed generally at a crustal depth of a few to dozen kilometers. Therefore, the regions where young granites are exposed must have been uplifted and denuded at an extraordinary high rate. Granites younger than $\sim 5$ Ma have been discovered basically along convergent plate boundaries (Harayama 1992). In the Japanese Islands, such young granites have been reported along arc-arc junctions in central Japan based on zircon $\mathrm{U}-\mathrm{Pb}$ dating, e.g., 10-0.8 Ma in the Hida range, Northern Japan Alps (Ito et al. 2013) and $\sim 4 \mathrm{Ma}$ in the Tanzawa mountains, Izu collision zone (Tani et al. 2010). The Tanigawadake region, southern end of the Northeast Japan Arc, can also involve young granites (Sato 2016) considering the young cooling ages (Ganzawa and Kubota 1987; Kawano et al. 1992; Ohira and Honda 1999; Kubo et al. 2013; Sato 2016) although this region is located away from the arc-arc junctions. For instance, $\mathrm{Rb}-\mathrm{Sr}$ age of whole rock is estimated to be $5.27 \pm 1.28$ Ma representing formation age of the granite (Ohira et al. 1998; Ohira and Honda 1999). Biotite K-Ar ages are 3.9-3.1 Ma (Kawano et al. 1992; Sato 2016), whose closure temperature is $350-400{ }^{\circ} \mathrm{C}$ (Harrison et al. 1985; Grove and Harrison
1996). Zircon fission-track ages are 3.3-2.9 Ma (Ohira and Honda 1999), whose closure temperature is 250 $350^{\circ} \mathrm{C}$ (Yamada et al. 2007; Ketcham 2019). However, the previous studies have two problems to estimate the intrusive age: (1) $\mathrm{Rb}-\mathrm{Sr}$ age was obtained only from a single locality and has a large error, and (2) biotite K-Ar ages and zircon fission-track ages are cooling ages, probably younger than the intrusive ages. Thus, this study aims to estimate the reliable intrusive ages. We collected samples from the intrusive bodies and applied zircon $\mathrm{U}-\mathrm{Pb}$ dating, as well as the late Cretaceous granites intruded by the young plutons.

\section{Geology and sampling}

The Tanigawa-dake area is located on the back-arc side of the Northeast Japan Arc. Mt. Tanigawa-dake (1977 m high) is a non-volcanic mountain surrounded by Quaternary volcanoes, such as, Mt. Naeba, Mt. Iiji and Mt. Hotaka (Fig. 1). Coastal areas of the Sea of Japan, including the Tanigawa-dake area, is one of the heaviest snow areas in the world (e.g., Ueda et al. 2015). In addition, glacial landforms formed at the last glacial period are distributed in the Tanigawa-dake and adjacent mountains 


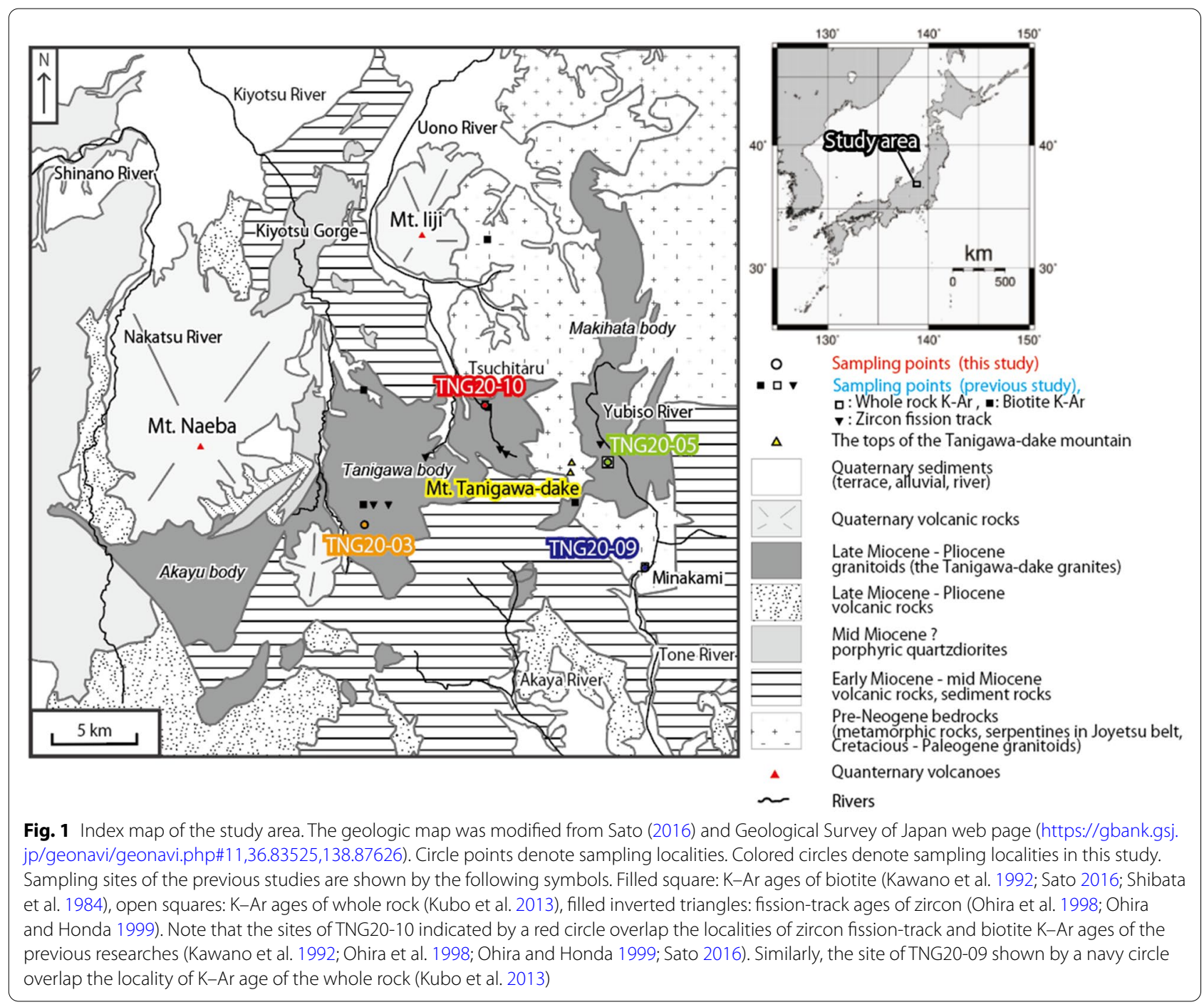

(Koaze 2002). Therefore, although the uplift mechanism is not well-known, the Tanigawa-dake region is expected to be denuded rapidly enough to expose the Pliocene plutons.

Lithology of the Tanigawa-dake area consists mainly of Cretaceous to Paleogene granitoids, late Miocene to Pliocene granitoids, and Miocene to Quaternary volcanic rocks (Sato 2016: Fig. 1). The late Miocene to Pliocene granites are called the Tanigawa-dake granites, being subdivided into three bodies, i.e., the Makihata body, the Tanigawa body, and the Akayu body, from east to west (Chihara et al. 1981). The Makihata body and the Tanigawa body are exposed on the eastern and western sides of Mt. Tanigawa-dake, respectively. The Akayu body is distributed on the southern side of Mt. Naeba. The late Cretaceous plutonic rock is called the Minakami quartzdiorite (Kubo et al. 2013; Sato 2016) which is distributed to the southeast of Mt. Tanigawadake. In the previous studies, these rocks were dated based on fission-track dating of zircon and apatite, $\mathrm{K}-$ Ar dating of biotite and whole rock, and $\mathrm{Rb}-\mathrm{Sr}$ dating of whole rock. The biotite $\mathrm{K}-\mathrm{Ar}$ (3.9-3.1 Ma; Kawano et al 1992; Sato, 2016) and zircon fission-track ages (3.3-2.9 Ma; Ohira et al. 1998; Ohira and Honda 1999) are consistent with each other within error range of 2 sigma regardless of location. Therefore, cooling ages of the Tanigawa-dake granites were spatially uniformed at $\sim 250-400{ }^{\circ} \mathrm{C}$. However, thermal histories above the temperature range were not well-known, including the timing of the intrusion of the Tanigawa-dake granites. In this study, for obtaining clearly intrusive ages of the Tanigawa-dake granites and intruded granites, we collected 4 rock samples: TNG20-03 and TNG20-10 from the Tanigawa body, TNG20-05 from the Makihata 
Table 1 Summary of dating results

\begin{tabular}{|c|c|c|c|c|c|c|c|}
\hline \multirow[t]{2}{*}{ Body name } & \multirow[t]{2}{*}{ Sample } & \multirow[t]{2}{*}{ Lithology } & \multicolumn{2}{|l|}{ Locality } & \multicolumn{2}{|l|}{$\mathrm{U}-\mathrm{Pb}$ ages (Ma) } & \multirow{2}{*}{$\begin{array}{l}\text { Number } \\
\text { of grains }\end{array}$} \\
\hline & & & Longitude & Latitude & Concordia Age & \pm 2 sigma & \\
\hline Tanigawa & TNG20-03 & Granodiorite & $138^{\circ} 47^{\prime} 39.93^{\prime \prime E}$ & $36^{\circ} 48^{\prime} 28.31 " \mathrm{~N}$ & 3.18 & 0.13 & 29 \\
\hline Makihata & TNG20-05 & Porphyritic granites & $138^{\circ} 57^{\prime} 7.45^{\prime \prime} \mathrm{E}$ & $36^{\circ} 50^{\prime} 27.19^{\prime \prime} \mathrm{N}$ & 3.95 & 0.11 & 30 \\
\hline Minakami & TNG20-09 & Quartzdiorite & $138^{\circ} 58^{\prime} 34.44^{\prime \prime} \mathrm{E}$ & $36^{\circ} 47^{\prime} 6.50^{\prime \prime} \mathrm{N}$ & 109.4 & 2.2 & 29 \\
\hline \multirow[t]{5}{*}{ Tanigawa } & TNG20-10 & Granodiorite & $138^{\circ} 52^{\prime} 16.74^{\prime \prime} \mathrm{E}$ & $36^{\circ} 52^{\prime} 5.04^{\prime \prime} \mathrm{N}$ & 3.32 & 0.15 & 20 \\
\hline & OD-3-A & & & & 33.4 & 2.8 & 4 \\
\hline & OD-3-B & & & & 33.1 & 1.8 & 6 \\
\hline & OD-3-C & & & & 32.9 & 2.1 & 3 \\
\hline & OD-3-D & & & & 32.0 & 2.0 & 3 \\
\hline
\end{tabular}

The reference age of OD-3 is $33.0 \pm 0.1 \mathrm{Ma}$ ( \pm 2 sigma) (Iwano et al. 2013)

body, and TNG20-09 from the Minakami quartzdiorite (Fig. 1, Table 1).

\section{U-Pb zircon dating method}

Zircon grains were separated from the granitoid samples by crushing, sieving, panning, magnetic separation and heavy liquid techniques. The zircon grains were mounted in resin (SpeciFix, Struers ApS, Denmark) and then used for cathodoluminescence (CL) observation and $\mathrm{U}-\mathrm{Pb}$ isotopic analysis using field-emission electron probe microanalyzer (FE-EPMA, JEOL JXA8530F) and multiple collector inductively coupled plasma mass spectrometer (Neptune-Plus, Thermo Fisher Scientific, Bremen, Germany) with an excimer laser system (Analyte G2; Photon Machines, Redmond, WA, USA) (LA-MC-ICP-MS), respectively, at Tono Geoscience Center, JAEA. Elemental fractionation and instrumental mass bias on ${ }^{206} \mathrm{~Pb} /{ }^{238} \mathrm{U},{ }^{207} \mathrm{~Pb} /{ }^{206} \mathrm{~Pb}$ ratios were corrected using the measured isotope ratio of the 91,500 zircon (Wiedenbeck et al. 1995) as primary standard with a standard-sample bracketing approach. The OD-3 zircon (Iwano et al., 2013) was used as secondary standard material for age quality control. The details of analytical setting are summarized in Additional file 1: Table S1. The analytical spots of unknowns were determined based on the growth structures of zircons observed by CL images (Fig. 2); the structures show oscillatory zoning patterns (e.g., 1-TNG2005-01, 1-TNG20-09-04) or homogeneous textures (e.g., 1-TNG20-03-13, TNG20-10-08). The zircon grains were measured for each of the 4 samples, and the results are summarized in Table 1 (for the details, see also Additional file 2: Table S2). In this paper, the data were defined as 'concordant' when overlapping the concordia curve on a concordia diagram within error range of 1sigma. Isoplot software ver. 4.15 (Ludwig 2012) was used to produce the concordia diagrams and the concordia ages (2 sigma-weighted mean age of ${ }^{207} \mathrm{~Pb} /{ }^{235} \mathrm{U}$ and ${ }^{206} \mathrm{~Pb} /{ }^{238} \mathrm{U}$ isotopes; Ludwig, 1998) using the 'concordant' data (Fig. 2).

\section{Results and geo-/thermo-chronologic interpretation}

Summaries of the dating results are shown in Table 1 and Fig. 2; uncertainties of the ages indicate 2 sigma. Zircon $\mathrm{U}-\mathrm{Pb}$ ages of OD-3 (secondary standard) were computed to be $33.4 \pm 2.8 \mathrm{Ma}, 33.1 \pm 1.8 \mathrm{Ma}, 32.9 \pm 2.1 \mathrm{Ma}$, $32.0 \pm 2.0 \mathrm{Ma}$. These ages are consistent with the reference age (33.0 $\pm 0.1 \mathrm{Ma}, 2$ sigma; Iwano et al. 2013) within the 2 sigma error range.

The concordia ages were calculated from 30 zircon grains for TNG20-05, 29 zircon grains for TNG20-03 and TNG20-09, and 20 zircon grains for TNG20-10. One discordant grain was identified in TNG20-03 and TNG20-09, respectively, which was removed from the concordia age calculation. Consequently, the concordia ages were calculated to be $3.18 \pm 0.13 \mathrm{Ma}$ for TNG2003, 3.95 $\pm 0.11 \mathrm{Ma}$ for TNG20-05, 3.32 $\pm 0.15 \mathrm{Ma}$ for TNG20-10 and 109.4 $\pm 2.2 \mathrm{Ma}$ for TNG20-09.

The zircon $\mathrm{U}-\mathrm{Pb}$ ages obtained in this study were compared with the reported cooling ages, i.e., $\mathrm{K}-\mathrm{Ar}$ ages of biotite and fission-track ages of zircon. The comparison did not include the $\mathrm{Rb}-\mathrm{Sr}$ age of whole rock and $\mathrm{K}-\mathrm{Ar}$ age of whole rock because the sampling point of $\mathrm{Rb}-\mathrm{Sr}$ age is unknown and the closure temperature of the two dating methods cannot be defined. The reported ages of the Tanigawa-dake granites are 3.9-3.1 Ma based on biotite KAr dating (Kawano et al. 1992; Sato 2016) and 3.3-2.9 Ma based on zircon fission-track dating (Ohira et al. 1998). The obtained zircon $\mathrm{U}-\mathrm{Pb}$ ages are consistent with the reported ages given the higher closure temperature $\left(>900^{\circ} \mathrm{C}\right.$; Cherniak and Watson 2000). Namely, zircon U-Pb ages are coincident with or older than the reported ages close to each sampling locality within the error range of 2 sigma. 


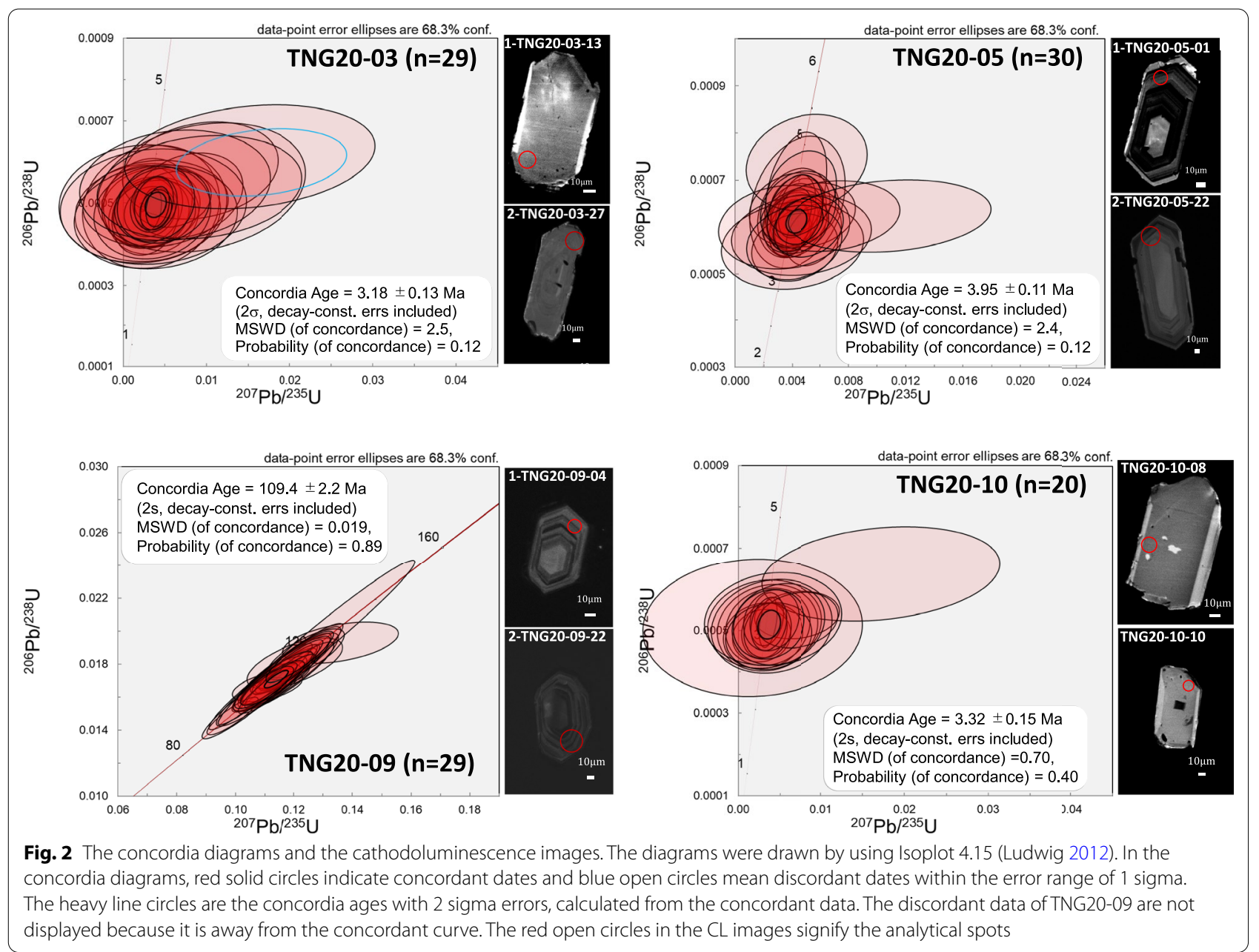

For the Minakami quartzdiorite, the K-Ar age of whole rock was estimated at $\sim 70 \mathrm{Ma}$ (Kubo et al. 2013), which is the only geochronologic datum reported previously. The zircon $\mathrm{U}-\mathrm{Pb}$ age is older than the $\mathrm{K}-\mathrm{Ar}$ age of whole rock by $40 \mathrm{Myr}$.

\section{Geological implication}

Based on the zircon U-Pb age of TNG20-09, the Minakami quartzdiorite might be correlated with the Tadamigawa granites. The Tadamigawa granites are located to the northeast of Mt. Tanigawa-dake, belonging to the Ashio belt. The Minakami quartzdiorite age is consistent with the oldest zircon $\mathrm{U}-\mathrm{Pb}$ age of the Tadamigawa granites $(106.7 \pm 0.6 \mathrm{Ma}$; $95 \%$ confidence interval: Wakasugi et al. 2020) within the error range of 2 sigma. As a result, the igneous activity to form the Minakami quartzdiorite is compared to the first igneous event to form the Tadamigawa granites. Namely, the Minakami quartzdiorite can be an associated body as the bedrock distributed in Ashio belt.
According to zircon U-Pb ages of TNG20-03, TNG2005 and TNG20-10, the Tanigawa body is considered to have intruded after the Makihata body. The intrusion age for the Tanigawa body was estimated to $\sim 3.3-3.2 \mathrm{Ma}$ because the zircon $\mathrm{U}-\mathrm{Pb}$ ages of TNG20-03 and TNG2010 in the Tanigawa body are consistent within error range of 2 sigma. On the other hand, zircon $\mathrm{U}-\mathrm{Pb}$ age of the Makihata body, TNG20-05, is significantly older than those of the Tanigawa body with error range of 2 sigma. Therefore, the Tanigawa body could have intruded 0.7 Myr later than the Makihata body. The Tanigawa-dake granites were estimated to be formed by at least two magmatism.

On the other hand, the previously reported cooling ages, i.e., biotite $\mathrm{K}-\mathrm{Ar}$ ages and zircon fission-track ages, are not significantly different for Makihata and Tanigawa bodies despite the different intrusive ages. The two possible reasons follow below: (1) the biotite $\mathrm{K}-\mathrm{Ar}$ and zircon fission-track ages of the Makihata body were reset by the thermal effect of the intrusion of the Tanigawa body, 
and (2) the Makihata body was more slowly cooled than the Tanigawa body from the intrusion to $\sim 250-400^{\circ} \mathrm{C}$. In either case, the Tanigawa body and the Makihata body might have experienced different cooling histories above $\sim 400{ }^{\circ} \mathrm{C}$.

\section{Conclusion}

To determine the intrusive ages, a sequence of zircon $\mathrm{U}-\mathrm{Pb}$ dating was performed for the Pliocene granites at 3 localities and late Cretaceous quartzdiorite at 1 locality in the Tanigawa-dake area. The ages of the Tanigawa body are 3.18 $\pm 0.13 \mathrm{Ma}$ for TNG20-03 and $3.32 \pm 0.15 \mathrm{Ma}$ for TNG20-10, the age of the Makihata body is $3.95 \pm 0.11 \mathrm{Ma}$ for TNG20-05, and the age of the Minakami quartzdiorite is $109.4 \pm 2.2 \mathrm{Ma}$ for TNG20-09. From these results, the age of the Minakami quartzdiorite is considered to correspond to the Tadamigawa granite, bedrock of the Ashio belts. Additionally, the Makihata body intruded earlier than the Tanigawa body by 0.7 Myr. Thus, the Tanigawadake granites are estimated to be formed by at least two times of magmatism, being among the youngest plutons exposed on Earth.

\section{Abbreviations}

JAEA: Japan Atomic Energy Agency; FE-EPMA: Field-emission electron probe microanalyzer; LA-MC-ICP-MS: Laser ablation-multiple collector inductivity coupled plasma Mass spectrometry; CL: Cathodoluminescence.

\section{Supplementary Information}

The online version contains supplementary material available at https://doi. org/10.1186/s40623-021-01556-4.

Additional file 1: Table S1. Analytical setting for zircon U-Pb dating.

Additional file 2: Table S2. Zircon U-Pb isotope data in this study.

\section{Acknowledgements}

Mineral separations were performed at Kyoto Fission-Track Co., Ltd. by Drs. T. Danhara and H. Iwano. Ms. A. Yamazaki helped with carbon vapor deposition.

\section{Authors' contributions}

SM drafted the most of the manuscript, and MN drafted the section of "Dating method". SM, SS, and TT are responsible for the project, conducting research planning, sampling, and data interpretation. SF, YK and YO carried out planning and sampling. MN, SK, YO and TY performed the U-Pb isotopic analyses with SM and assisted in drafting the manuscript. All authors read and approved the final manuscript.

\section{Funding}

This study was funded by the Ministry of Economy, Trade and Industry (METI), Japan, as part of its R\&D supporting program title "Establishment of Advanced Technology for Evaluating the Long-term Geosphere Stability on Geological Disposal Project of Radioactive Waste (Fiscal Year 2021) (JPJ007597)".

\section{Availability of data and materials}

The data for this paper are presented in the tables and supplementary information.

\section{Declarations}

Ethics approval and consent to participate

Not applicable.

\section{Consent for publication}

Not applicable.

\section{Competing interests}

The authors declare that they have no competing interests.

\section{Author details}

${ }^{1}$ Department of Geology and Mineralogy, Graduate School of Science, Kyoto University, Oiwake-cho, Kitashirakawa, Sakyo-ku, Kyoto 606-8502, Japan.

${ }^{2}$ Tono Geoscience Center, Japan Atomic Energy Agency (JAEA), 959-31, Jorinji, Izumi-cho, Toki 509-5102, Japan.

Received: 8 October 2021 Accepted: 3 December 2021

Published: 16 December 2021

\section{References}

Cherniak DJ, Watson EB (2000) Pb diffusion in zircon. Chem Geol 172:5-24 https://doi.org/10.1016/S0009-2541(00)00233-3

Chihara K, Komatsu M, Shimazu M, Kubota Y, Shiokawa S (1981) Geology of Echigo Yuzawa Distinct, Quadrangle Series, Scale 1:50,000, Geological Survey of Japan, 108 pp.

Ganzawa Y, Kubota Y (1987) Geological setting of Tanigawa-quartz diorite and its cooling history. Abst 94th Annu Meet Geol Soc Jpn. https://doi.org/10. 14863/geosocabst.1987.0_194

Grove M, Harrison TM (1996) ${ }^{40} \mathrm{Ar}$ * diffusion in Fe-rich biotite. Am Miner 81:940-951. https://doi.org/10.2138/am-1996-7-816

Harayama S (1992) Youngest exposed granitoid pluton on earth: cooling and rapid uplift of the Pliocene-Quaternary Takidani Granodiorite in the Japan Alps, central Japan. Geology 20:657-660. https://doi.org/10.1130/00917613(1992)020\%3c0657:YEGPOE\%3e2.3.CO;2

Harrison TM, Duncan IAN, Mcdougall IAN (1985) Diffusion of ${ }^{40} \mathrm{Ar}$ in biotite: temperature, pressure and compositional effects. Geochim Cosmochim Acta 49:2461-2468. https://doi.org/10.1016/0016-7037(85)90246-7

Ito H, Yamada R, Tamura A, Arai S, Horie K, Honda T (2013) Earth's youngest expose granite and its tectonic implications; the 10-0.8 Ma Kurobegawa Granite. Sci Rep 3:1306. https://doi.org/10.1038/srep01306

Iwano H, Orihashi Y, Iwata T, Ogasawara M, Danhara T, Horie K, Hasebe N, Sueoka S, Tamura A, Hayasaka Y, Katube A, Ito H, Tani K, Kimura J, Chang Q, Kouchi Y, Haruta Y, Yamamoto K (2013) An inter-laboratory evaluation of OD-3 zircon for use as a secondary U-Pb dating standard. Island Arc 22:382-394. https://doi.org/10.1111/iar.12038

Kawano Y, Shibata K, Uchiumi S, Ohira H (1992) K-Ar age of the Tanigawadake Pliocene plutonic body, North Fossa Magna, central Japan. J Mineral Petrol Econ Geol (ganko) 87:221-225. https://doi.org/10.2465/ganko.87.221

Ketcham RA (2019) Fission-track annealing: from geologic observations to thermal history modeling. In: Malusà M, Fitzgerald $P$ (eds) Fission-track thermochronology and its application to geology. Springer textbooks in earth sciences, geography and environment. Springer, Cham, pp 49-75 (10.1007/978-3-319-89421-8_3)

Koaze T (2002) Study of the Echigo mountains, central Japan. Meiji Univ Inst Human Bull 50:163-175

Kubo S, Nakazima K, Murayama A, Suzuki Y (2013) Geology of the Southeast foot of Mt. Tanigawa and K-Ar ages of Minakami granodiorite and Machigasawa granite porphyry. Bull Gunma Mus Nat Hist 17:119-130

Ludwig KR (1998) On the treatment of concordant uranium-lead ages. Geochim Cosmochim Acta 62:665-676. https://doi.org/10.1016/S00167037(98)00059-3

Ludwig KR (2012) Isoplot 3.75: A geochronological toolkit for Microsoft Excel, Spec. Publ., no. 5, Berkeley Geochronology Center, Berkeley, California, $75 p$. 
Ohira H, Honda T (1999) Fission track age Th/U abundance ratio of zircon from the Tanigawadake Pluton, North Fossa Magna, Central Japan. Fission Track News Lett 12:61-63

Ohira H, Kondo K, Izumi S, Kawano Y (1998) Fission Track and Rb-Sr whole rock age of the Tanigawadake Pluton, North Fossa Magna, Central Japan. Abst 105th Annu Meet Geol Soc Jpn. https://doi.org/10.14863/geosocabst. 1998.0_044

Sato K (2016) Age of the Tanigawa-dake granitoid pluton and its relevance to the Neogene felsic magmatism in the Fossa Magna region, an island-arc junction, central Japan. Bull Gunma Mus Nat His 20:85-104

Shibata K, Uchiumi S, Uto K, Nakagawa T (1984) K-Ar age results_-2_new data from the Geological Survey of Japan. Bull Geol Surv Japan 35:331-340

Tani K, Dunkley JD, Kimura J, Wysoczanski JR, Yamada K, Tatsumi Y (2010) Syncollisional rapid granitic magma formation in an arc-arc collision zone: evidence from the Tanzawa plutonic complex, Japan. Geology 38:215-218. https://doi.org/10.1130/G30526.1

Ueda H, Kibe A, Saitoh M, Inoue T (2015) Snowfall variations in Japan and its linkage with tropical forcing. Int J Climatol 35:991-998. https://doi.org/10 1002/joc.4032

Wakasugi Y, Wakaki S, Tanioka Y, Ichino K, Tsuboi M, Asahara Y, Noda A (2020) A chronological and geochemical study of the Tadamigawa older-stage granites: Igneous activity in the west of the Tanakura Tectonic Line (TTL) of northeastern Japan. Geochem J 54:203-220. https://doi.org/10.2343/ geochemj.2.0603

Wiedenbeck M, Alle P, Corfu FY, Griffin WL, Meier M, Oberli F, Von Quadt A, Roddick JC, Spiegel W (1995) Three natural zircon standards for U-Th-Pb, Lu-Hf, trace element and REE analyses. Geostandards Newslett 19(1):1-23. https://doi.org/10.1111/j.1751-908X.1995.tb00147X

Yamada R, Murakami M, Tagami T (2007) Statistical modelling of annealing kinetics of fission tracks in zircon; Reassessment of laboratory experiments. Chem Geol 236:75-91. https://doi.org/10.1016/j.chemgeo.2006. 09.002

\section{Publisher's Note}

Springer Nature remains neutral with regard to jurisdictional claims in published maps and institutional affiliations.

\section{Submit your manuscript to a SpringerOpen ${ }^{\circ}$ journal and benefit from:}

- Convenient online submission

- Rigorous peer review

- Open access: articles freely available online

- High visibility within the field

- Retaining the copyright to your article

Submit your next manuscript at $\boldsymbol{\nabla}$ springeropen.com 